\title{
Professional Competence Development of Social Studies Teacher in Thailand Education Sandbox
}

\author{
Charin Mangkhang ${ }^{1} \&$ Korravit Jitviboon ${ }^{1}$ \\ ${ }^{1}$ Faculty of Education, Chiang Mai University, Thailand \\ Correspondence: Charin Mangkhang, Faculty of Education, Chiang Mai University. 239 Huay Kaew Rd, Suthep, \\ Mueang District, Chiang Mai, Thailand 50200.
}

Received: August 20, 2021

Accepted: October 5, $2021 \quad$ Online Published: October 26, 2021

doi:10.5539/jel.v10n6p112

URL: https://doi.org/10.5539/jel.v10n6p112

\begin{abstract}
This research article deals with two objectives. The first objective was to develop the professional competence of social studies teacher in the education sandbox. The second objective was to propose social studies classroom-based action learning management innovation to develop professional competence of social studies teacher in the education sandbox and to assess satisfaction levels of students in developing professional competence of social studies teacher in the education sandbox. The conducted research in this article was classroom-based action research whereby the assessment form of area-based competence perception of educational students in Chiang Mai education sandbox, Faculty of Education, Chiang Mai University (pre- and post-assessment). The sample group used in the research consisted of senior educational students in the field of social studies of the second semester of the academic year 2020 accounting for 30 people. For the analysis, descriptive statistics were used. Results of statistical data analysis were shown as mean and standard deviation.

From the research results, it was found that the level of perceived competence of becoming a professional teacher in Thailand education sandbox consisted of 3 aspects. 1) For the aspect of self-efficacy regarding knowledge and understanding in becoming a professional teacher, the average summation of the 4 competencies was as follows: the perception was at a high level. 2) For the aspect of skills and capacity in becoming a professional teacher in the Chiang Mai education sandbox, the average summation of 4 competencies was as follows: the perception was at a high level. 3) For the aspect of attitudes on becoming a professional teacher in the Chiang Mai education sandbox, the average summation of 4 competencies was as follows: the perception was at a high level.
\end{abstract}

Keywords: professional competence development, social studies teacher, Thailand education sandbox

\section{Introduction}

Education is an important instrument in building people, society, and the nation. It is the main mechanism in developing the manpower to have qualities so that one can live with other people in the society happily in the stream of rapid changes of the 21st-century world. Because education has an important role in building advantages of the country under the dynamic economic and social system, countries all over the world place importance on and devote themselves to developing education. The objective of this is to develop their human resources to keep up with changes in the economic and social system of the country, the region, and the world together with maintaining national identities. Thailand places importance on educational management, developing potentials and capabilities so that the Thai people will have skills, knowledge competency, and competencies in line with the needs of the labor market and national development, including having good life qualities. The Thai society is a moral and ethical society and Thailand can step over the middle-income trap to become a developed country to support present and future global changes through important changes, influencing the educational system, and the economic and social system of Thailand (Office of the Education Council, 2017).

The concept of managing competency-based education which is the innovation focusing on developing students' potentials (Ralf, Kunst, van Woerkom, Wesselink, \& Poell, 2020) and has used the concept of social studies pedagogy managing classroom-based action learning in social studies have been used as a conceptual framework in managing professional competence of social studies teacher in Thailand education sandbox (Mangkhang \& Kaewpanya, 2021). This is characterized as a cycle of checking to teach and learning systematically followed by 
improvement driven with the data resulting from inspection outcomes, which gives choices in developing professions not only valuable but also useful. This approach allows teachers to check their practices and search for what is effective and not effective for students in the classroom. There are discussions regarding action research integration with working together professionally and teacher assessment (Mertler, 2013). In producing social studies teachers to obtain competency according to Thai Qualifications Framework for Higher Education (QTF: HED) B. E. 2552 and the announcement of Ministry of Education on the qualification standard of bachelor's degrees in the field of pedagogy and education (4-year program) B. E. 2562, the standard of learning results has been determined for 6 aspects by integrating learning results in the specific subject cluster and major subjects with following details: 1) moral ethics; 2) knowledge; 3) cognitive skills; 4) skills of relationships between people and responsibilities; 5) skills of numerical analysis, communication and using technology; and 6) methodology of learning management (Government Gazette, 2019). Chiang Mai Educational Reform Strategic Plan B. E. 2559-2562 originated from partnership participation and every sector in the area of Chiang Mai province, following the footstep since the beginning of educational reform by people in Chiang Mai province occupying the Chiang Mai area as the establishing center. This has been done for the maximum benefit of the people of Chiang Mai for every group indeed. This strategic plan is considered to be a plan capable of being flexible, which is a process of adapting to changing situations to focus on managing the education of Chiang Mai province so that it will have qualities according to various potentials, responding to the strategic goal for 5 aspects, namely 1) building conscience in being people of Chiang Mai, 2) developing qualities of learners in the 21 st century with various curriculum and learning processes, 3) promoting the organization of education to have honest livelihood with qualities, 4) promoting teachers' organization of learning and teaching and administrators' management to become efficient, including changing attitudes of teachers and parents, and 5) building cooperation networks of educational management for every sector in the province and increasing international competitiveness. This is considered to be an important instrument which is a road map helping bring about good coordination with unity and corresponding understanding in terms of goals and missions. Moreover, it also helps increase more success in operating systematic area-based educational reform. There have been new educational innovations and creations as well as leading to making mutual agreements and announcing to be an important agenda for people of Chiang Mai. This is considered to be the starting point of important area-based educational reform for Thailand's educational reform (Chiang Mai Educational Reform Strategic Plan B. E. 2558, 2013).

Currently, there has been an announcement of using Education Sandbox Act B. E. 2562 effective on B. E. 2019. This has been done due to the need of developing management of basic education which is an important foundation for developing the Thai people to be quality citizens, to awareness learning by inquiry knowledge, and to have communication capabilities. They should be able to live and work together with other people who are different from them, to keep up with the knowledge of the world and each learner has skills in earning a living according to his aptitude. Moreover, the state, local government, private sectors, and civil society should be assigned to develop qualities and efficiency, and reduce differences in educational management (Government Gazette, 2019). According to Tangkitvanich (2020), education sandbox is an experimental area in education that gives schools and teachers freedom to experiment with the new concept and the new method to build quality learning for the benefit of every child. This is in line with Terry Heick (2020) stating that education sandbox is an area for learning by determining the scope of learning. Moreover, it is educational management to be consistent with local conditions and needs and the requirement of the civil society covering every target group so that it will receive educational opportunities with equity and equality (Mangkhang, 2017).

Developing educational students' competence to support education sandbox schools by using the research and development process in suporting schools in the education sandbox will facilitator educate students in terms of designing curriculum and innovations of learning management suitable with the area-based context, developing the competence-based method of measuring and assessing results in the context of learners with cultural differences and diversities, and designing the use of technology to manage to learn suitable with the invented curriculum and innovations of learning management. Regarding the research on and developing educational students' competence to support educational management in education sandbox schools, there is an important competence for 3 aspects, namely 1) research, 2) designing and developing curriculum, and 3) caring for special children. Teachers' Council Directorate Committee has determined rules and methods of testing and assessing teaching profession competence B. E. 2563 whereby there are methods and conditions for applying for a teaching license used as a part of the mechanism and the system of screening teaching professionals to get professional teachers with teaching spirit and have knowledge and abilities according to the teacher professional standard determined by the Teachers' Council. Teacher professional competence consists of 2 parts: Part 1 refers to knowledge and professional experiences according to the teacher profession standard, namely subjects of languages and digital technology consisting of 1) use of the Thai language for communication, 2) use of English 
for communication and 3) relationships with parents and the community and 3) use of digital technology for education.; Part 2 refers to performing and behaving according to the professional standard for teachers, namely 1) learning management, 2) relationships with parents and the community, 3) performing teacher duties and professional ethics (Government Gazette, 2020). This is in line with Mangkhang (2017) stating that professional competency refers to abilities related to educational technology, learning evaluation, and abilities to teach specific subjects for developing learners' qualities in specific subjects with the integration of students using it in operation training according to the professional standard frame in the course. This consists of developing school curriculum, organization of learning and teaching, using information technology media in the organization of learning and teaching, controlling and managing the classroom through professional work experience training. Therefore, constructing quality teachers is an important mechanism that will drive educational management so that the school can develop learners' qualities. In fact, regarding educational agencies related to teacher production and teacher quality-supervising agencies, each of them has determined teacher competence which will promote teachers to be able to manage to learn to develop learners to achieve the goal of educational reform. People's competence is a characteristic reflecting knowledge, skills, attitudes, belief, and characters of individuals, which will promote individuals and organizations to achieve the goal. Teacher competence which shows essential knowledge, abilities, skills, and characteristics of teachers will facilitator and support the performance of duties and responsibilities and learning management to achieve the purpose, abilities to create achievement according to positions and duties, resulting in the success of the school (Wannasri, 2009). Teachers are the ones who have important roles in the learning process with the mission to bring about a learning environment supportive and efficient for students in successful adjusting and training in the university (Smolikevych, 2019). For educational leadership must place a premium on integrating spatial identity in the community as a foundation for managing many aspects of learning. For example, community history, community geography, ethnic culture, Buddhist art history, and ecoculture (Mangkhang, Kaewpanya, Sombun, \& Pangchan, 2021).

Therefore, professional competence development of social studies teachers in Thailand education sandbox has used the concept of competency-based learning and teaching management and managing classroom-based action learning in social studies as a conceptual framework in professional competence development of social studies teachers in Thailand education sandbox. The objective for this is to develop activities and forms of promoting the competence of educational students using design-based learning innovation and area-based learning through micro-instructional activities. This also includes preparing and training professional experiences as well as using new style learning and teaching innovation of educational students to be the mechanism of developing educational qualities of learners. This development will help support education sandbox schools.

\section{Objectives}

1) To develop professional competence of social studies teachers in education sandbox.

2) To propose innovation of managing classroom-based action learning in social studies to develop professional competence of social studies teachers in education sandbox.

3) To assess the level of satisfaction in developing professional competence of social studies teachers in the education sandbox.

\section{Method}

\subsection{Research Design}

This study was a Mixed Method in Education Research using qualitative research methodology for data collection and data analysis obtained from questionnaires. The quantitative research methodology was used for data collection and data analysis obtained from the assessments, for the presentation of the study results of the study in Descriptive Analysis using quantitative and qualitative data for data synthesis and description.

\subsection{Population and Sample Group}

Population and the sample group used in the study consisted of main target groups in 2 periods: 1) For the experiment used in the first period, population and the sample group used in the study consisted of educating students in the field of social studies, Faculty of Education, Chiang Mai University, accounting for 172 people. The researcher used purposive sampling to experiment using the form of developing educational students' competence to support schools in the Chiang Mai education sandbox with senior educational students of the second semester, the academic year 2020, accounting for 30 people.

2) The experiment used in the second period consisted of educational students in the field of social studies, Faculty of Education, Chiang Mai University, accounting for 172 people. The researcher used purposive 
sampling to obtain 30 senior educational students in the field of social studies of the second semester, the academic year 2020 to experiment using the form of developing educational students' competence in Chiang Mai education sandbox schools for all 15 schools, accounting for the number of not less than 4 schools.

\subsection{Research Tools}

1) The assessment form of area-based competence perception of educational students in Chiang Mai education sandbox, Faculty of Education, Chiang Mai University (pre- and post-assessment)

2) The assessment form of satisfaction level of students in developing professional competence of social studies teachers in education sandbox.

\subsection{Method of Collecting Data}

For data collection, the assessment form of area-based competence perception of educational students in Chiang Mai education sandbox, Faculty of Education, Chiang Mai University (pre- and post-assessment) and assessment form of satisfaction level of students in developing professional competence of social studies teachers in education sandbox. For senior educational student in the field of social studies of the second semester, the academic year 2020, accounting for 30 people was used to assess area-based competence perception and satisfaction level of educational students in Chiang Mai education sandbox.

\subsection{Data Analysis}

For data analysis, the researcher took the data obtained from the assessment form to conduct data analysis by using the statistical package which could analyze the data efficiently. The analysis was conducted by using descriptive statistics. Results of the analysis of statistical data were shown as mean and standard deviation.

The researcher used the appropriateness assessment form of 5-level rating scale: at the highest level; a high level; a medium level; a low level; and the lowest level by determining suitable values of each range of scores and meanings as follows:

Level 5 means having abilities in perceiving the mentioned matter at the highest level

Level 4 means having abilities in perceiving the mentioned matter at a high level

Level 3 means having abilities in perceiving the mentioned matter at a medium level

Level 2 means having abilities in perceiving the mentioned matter at a low level

Level 1 means having abilities in perceiving the mentioned matter at the lowest level

For giving a meaning to the measured value, the researcher determined criteria used for giving a meaning based on the concept of Nilkaew (1998) as follows:

4.50-5.00 means having abilities in perceiving the mentioned matter at the highest level

3.50-4.49 means having abilities in perceiving the mentioned matter at a high level

2.50-3.49 means having abilities in perceiving the mentioned matter at a medium level

1.50-2.49means having abilities in perceiving the mentioned matter at a low level

0.50-1.49 means having abilities in perceiving the mentioned matter at the lowest level

and for satisfaction level assessment, the researcher determined criteria used for giving a meaning based on modifying the concept of Nilkaew (1998) as follows:

4.50-5.00 means satisfaction at the highest level

3.50-4.49 means satisfaction at a high level

2.50-3.49 means satisfaction at a medium level

$1.50-2.49$ means satisfaction at a low level

$0.50-1.49$ means satisfaction at the lowest level

The data obtained from the questionnaire were taken to be analyzed, synthesized, summarized. Then, professional competence of social studies teachers in Chiang Mai education sandbox was presented in order to be used with educational students in the field of social studies in higher education institutions of Chiang Mai province further.

\section{Results}

The results are classified follows specific objectives and presented in 3 dimensions as follows; 
The objective of Clause 1 was to develop the professional competence of social studies teachers in the Chiang Mai education sandbox. Regarding research results, it was found that the level of perceived competence of becoming a professional teacher for 4 competencies: Competence 1-Content Knowledge; Competence 2-Learning Management; Competence 3-Engagement Strategies; and Competence 4-Professional Development had 3 aspects consisting of 1) Self-efficacy regarding the understanding of becoming a professional teacher. 2) Skills and abilities in becoming a professional teacher in Chiang Mai Education Sandbox Area. 3) Attitudes on becoming a professional teacher in Chiang Mai Education Sandbox Area.

Table 1. Self-efficacy regarding understanding of becoming a professional teacher

\begin{tabular}{|c|c|c|c|c|c|c|}
\hline \multirow[t]{2}{*}{ Order } & \multirow[t]{2}{*}{ Item } & \multicolumn{2}{|c|}{ Before learning } & \multicolumn{2}{|c|}{ After learning } & \multirow{2}{*}{$\begin{array}{l}\text { Level of } \\
\text { perception }\end{array}$} \\
\hline & & $\overline{\mathrm{x}}$ & SD & $\overline{\mathrm{x}}$ & SD & \\
\hline \multicolumn{7}{|c|}{ Competence1 : Content Knowledge } \\
\hline 1 & Being very knowledgeable about the content of major subjects & 3.76 & 0.72 & 4.23 & 0.56 & high \\
\hline 2 & $\begin{array}{l}\text { Having knowledge and understanding of developing } \\
\text { curriculum consistent with their local areas }\end{array}$ & 3.70 & 0.87 & 4.37 & 0.55 & high \\
\hline 3 & $\begin{array}{l}\text { Being very knowledgeable about the school and community } \\
\text { context }\end{array}$ & 3.56 & 0.85 & 4.20 & 0.76 & high \\
\hline 4 & $\begin{array}{l}\text { Having interdisciplinary knowledge to be applied with the } \\
\text { community context }\end{array}$ & 3.76 & 0.81 & 4.27 & 0.74 & high \\
\hline & Average summation & 3.70 & 0.81 & 4.27 & 0.65 & high \\
\hline \multicolumn{7}{|c|}{ Competence2 : Learning Management } \\
\hline 5 & $\begin{array}{l}\text { Being well-informed in technology or new knowledge in their } \\
\text { fields or related fields }\end{array}$ & 3.46 & 0.77 & 4.20 & 0.66 & high \\
\hline 6 & $\begin{array}{l}\text { Being very knowledgeable about trend of changes of various } \\
\text { technologies and the technology related to major }\end{array}$ & 3.53 & 0.86 & 4.20 & 0.76 & high \\
\hline 7 & $\begin{array}{l}\text { Understanding educational policies at the area level, national } \\
\text { level, regional level and the global level }\end{array}$ & 3.33 & 0.79 & 4.13 & 0.73 & high \\
\hline 8 & $\begin{array}{l}\text { Having knowledge and understanding in building professional } \\
\text { networks }\end{array}$ & 3.46 & 0.90 & 4.30 & 0.79 & high \\
\hline & Average summation & 3.45 & 0.83 & 4.21 & 0.74 & high \\
\hline \multicolumn{7}{|c|}{ Competence3 : Engagement Strategies } \\
\hline 9 & $\begin{array}{l}\text { Having techniques and strategies in learning management } \\
\text { consistent with the area }\end{array}$ & 3.36 & 0.77 & 4.40 & 0.67 & high \\
\hline 10 & $\begin{array}{l}\text { Having knowledge and abilities in producing medias and } \\
\text { innovation to be in line with learning and area management }\end{array}$ & 3.80 & 0.84 & 4.37 & 0.66 & high \\
\hline & Average summation & 3.58 & 0.81 & 4.39 & 0.67 & high \\
\hline \multicolumn{7}{|c|}{ Competence4 : Professional Development } \\
\hline 11 & $\begin{array}{l}\text { Having knowledge and understanding about educational } \\
\text { psychology and developmental psychology in implementing } \\
\text { them with learners correctly and suitably }\end{array}$ & 3.70 & 0.79 & 4.47 & 0.68 & high \\
\hline 12 & $\begin{array}{l}\text { Having knowledge and understanding about measuring and } \\
\text { assessing learning correctly }\end{array}$ & 3.66 & 0.80 & 4.27 & 0.64 & high \\
\hline \multirow[t]{2}{*}{13} & $\begin{array}{l}\text { Having knowledge about educational philosophy, educational } \\
\text { psychology and educational social science }\end{array}$ & 3.60 & 0.81 & 4.40 & 0.62 & high \\
\hline & Average summation & 3.65 & 0.80 & 4.38 & 0.65 & high \\
\hline
\end{tabular}


Table 2. Skills and abilities in becoming a professional teacher in Chiang Mai Education Sandbox Area

\begin{tabular}{|c|c|c|c|c|c|c|}
\hline \multirow[t]{2}{*}{ Order } & \multirow[t]{2}{*}{ Item } & \multicolumn{2}{|c|}{ Before learning } & \multicolumn{2}{|c|}{ After learning } & \multirow{2}{*}{$\begin{array}{l}\text { Level of } \\
\text { perception }\end{array}$} \\
\hline & & $\overline{\mathrm{x}}$ & SD & $\overline{\mathrm{x}}$ & SD & \\
\hline \multicolumn{7}{|c|}{ Competence1 : Content Knowledge } \\
\hline 1 & $\begin{array}{l}\text { Applying new curriculum and instruction development, } \\
\text { knowledge or technology in teaching operation }\end{array}$ & 3.80 & 0.76 & 4.47 & 0.50 & high \\
\hline 2 & $\begin{array}{l}\text { Solving problems caused by introduction of new } \\
\text { technology in learning and learning }\end{array}$ & 3.76 & 0.77 & 4.33 & 0.75 & high \\
\hline 3 & $\begin{array}{l}\text { Searching for knowledge regarding new technology and } \\
\text { knowledge to be used in learning management }\end{array}$ & 3.86 & 0.77 & 4.33 & 0.60 & high \\
\hline & Average summation & 3.81 & 0.77 & 4.38 & 0.62 & high \\
\hline \multicolumn{7}{|c|}{ Competence 2: Learning Management } \\
\hline 4 & $\begin{array}{l}\text { Being able to plan and design various learning activities } \\
\text { suitable and consistent with ages, needs of learners and the } \\
\text { community }\end{array}$ & 3.86 & 0.77 & 4.33 & 0.71 & high \\
\hline 5 & $\begin{array}{l}\text { Organizing the environment inside and outside the } \\
\text { classroom favorable for learning }\end{array}$ & 3.90 & 0.75 & 4.37 & 0.66 & high \\
\hline 6 & $\begin{array}{l}\text { Using the learning center and local wisdom in learning } \\
\text { management }\end{array}$ & 3.90 & 0.92 & 4.53 & 0.62 & the highest \\
\hline 7 & $\begin{array}{l}\text { Being able to measure and evaluate learning according to } \\
\text { actual conditions variously and appropriately with the } \\
\text { context }\end{array}$ & 3.56 & 0.77 & 4.23 & 0.77 & high \\
\hline 8 & $\begin{array}{l}\text { Using learning assessment results in improving learning } \\
\text { management and improving learners }\end{array}$ & 3.76 & 0.77 & 4.37 & 0.55 & high \\
\hline 9 & $\begin{array}{l}\text { Monitoring and evaluating students' learning by } \\
\text { comparing with standard criteria }\end{array}$ & 3.53 & 0.81 & 4.03 & 0.80 & high \\
\hline 10 & $\begin{array}{l}\text { Being able to use the principle of psychology in learning } \\
\text { management correctly and suitably with learners }\end{array}$ & 3.66 & 0.80 & 4.30 & 0.59 & high \\
\hline & Average summation & 3.74 & 0.80 & 4.31 & 0.67 & high \\
\hline \multicolumn{7}{|c|}{ Competence 3: Engagement Strategies } \\
\hline 11 & Helping the community even without being asked for & 3.73 & 0.82 & 4.13 & 0.73 & high \\
\hline 12 & $\begin{array}{l}\text { Implementing integrated knowledge in operation in the } \\
\text { area with ethnical differences and diversities }\end{array}$ & 3.83 & 0.74 & 4.27 & 0.69 & high \\
\hline 13 & $\begin{array}{l}\text { Coordinating within agencies and other related agencies so } \\
\text { that the community will receive good education } \\
\text { thoroughly }\end{array}$ & 3.50 & 0.86 & 4.20 & 0.71 & high \\
\hline 14 & $\begin{array}{l}\text { Allowing the community to participate in studying the } \\
\text { needs and using the data to improve and develop learning } \\
\text { and teaching }\end{array}$ & 3.80 & 0.76 & 4.27 & 0.69 & high \\
\hline 15 & $\begin{array}{l}\text { Being able to communicate in order to make decisions } \\
\text { together and solve problems in the community }\end{array}$ & 3.53 & 0.77 & 4.10 & 0.75 & high \\
\hline \multicolumn{7}{|c|}{ Competence 4: Professional Development } \\
\hline 16 & $\begin{array}{l}\text { Conducting research to solve learning problems and } \\
\text { develop learners }\end{array}$ & 3.60 & 0.81 & 4.17 & 0.74 & high \\
\hline 17 & $\begin{array}{l}\text { Applying research results in other study cases with similar } \\
\text { contexts }\end{array}$ & 3.56 & 0.78 & 4.27 & 0.69 & high \\
\hline \multirow[t]{2}{*}{18} & $\begin{array}{l}\text { Being determined and searching for knowledge, } \\
\text { opportunities to develop oneself with various methods }\end{array}$ & 3.76 & 0.77 & 4.53 & 0.62 & the highest \\
\hline & Average summation & 3.64 & 0.79 & 4.32 & 0.68 & high \\
\hline
\end{tabular}


Table 3. Attitudes on becoming a professional teacher in Chiang Mai Education Sandbox Area.

\begin{tabular}{|c|c|c|c|c|c|c|}
\hline \multirow[t]{2}{*}{ Order } & \multirow[t]{2}{*}{ Item } & \multicolumn{2}{|c|}{ Before learning } & \multicolumn{2}{|c|}{ After learning } & \multirow{2}{*}{$\begin{array}{l}\text { Level of } \\
\text { perception }\end{array}$} \\
\hline & & $\overline{\mathrm{x}}$ & SD & $\overline{\mathrm{x}}$ & SD & \\
\hline \multicolumn{7}{|c|}{ Competence 1: Content Knowledge } \\
\hline 1 & $\begin{array}{l}\text { Understanding and accepting area differences of the } \\
\text { people involved }\end{array}$ & 4.20 & 0.80 & 4.67 & 0.47 & the highest \\
\hline 2 & $\begin{array}{l}\text { Promoting learning networks development between } \\
\text { schools, parents and the community }\end{array}$ & 3.93 & 0.86 & 4.57 & 0.50 & the highest \\
\hline & Average summation & 4.07 & 0.83 & 4.62 & 0.49 & the highest \\
\hline \multicolumn{7}{|c|}{ Competence 2: Learning Management } \\
\hline 3 & $\begin{array}{l}\text { Supporting decision-making of colleagues and working in } \\
\text { their own part assigned }\end{array}$ & 4.16 & 0.83 & 4.47 & 0.68 & high \\
\hline 4 & $\begin{array}{l}\text { Collaborating with other people creatively and showing } \\
\text { confidence in colleagues' potentials }\end{array}$ & 4.10 & 0.80 & 4.40 & 0.67 & high \\
\hline 5 & $\begin{array}{l}\text { Listening to opinions and being willing to learn form } \\
\text { colleagues and the community }\end{array}$ & 4.30 & 0.79 & 4.63 & 0.55 & the highest \\
\hline 6 & $\begin{array}{l}\text { Making decision or planning together from opinions of } \\
\text { colleagues and involved people }\end{array}$ & 4.23 & 0.77 & 4.60 & 0.56 & the highest \\
\hline & Average summation & 4.20 & 0.80 & 4.53 & 0.62 & the highest \\
\hline \multicolumn{7}{|c|}{ Competence 3: Engagement Strategies } \\
\hline 7 & $\begin{array}{l}\text { Being willing, to, proud and happy in working in the } \\
\text { sandbox }\end{array}$ & 4.10 & 0.88 & 4.50 & 0.63 & the highest \\
\hline 8 & $\begin{array}{l}\text { Being willing, to allow the community to take part in } \\
\text { exchanging ideas and making comments regarding } \\
\text { working in the area with different cultures }\end{array}$ & 4.00 & 0.78 & 4.40 & 0.72 & high \\
\hline 9 & $\begin{array}{l}\text { Cooperating, offering help and promoting implementation } \\
\text { of democratic concept in the community }\end{array}$ & 4.03 & 0.76 & 4.40 & 0.67 & high \\
\hline & Average summation & 4.04 & 0.81 & 4.43 & 0.67 & high \\
\hline \multicolumn{7}{|c|}{ Competence 4: Professional Development } \\
\hline 10 & $\begin{array}{l}\text { Intending to develop knowledge, knowledge and abilities } \\
\text { of their own better }\end{array}$ & 4.13 & 0.81 & 4.47 & 0.68 & high \\
\hline 11 & $\begin{array}{l}\text { Following up new technology and knowledge at all time } \\
\text { by searching for data from sources }\end{array}$ & 3.96 & 0.76 & 4.30 & 0.65 & high \\
\hline 12 & $\begin{array}{l}\text { Making a determined effort and building motivation in } \\
\text { developing learners }\end{array}$ & 4.10 & 0.75 & 4.37 & 0.55 & high \\
\hline 13 & $\begin{array}{l}\text { Having the love of learning and taking the initiative in } \\
\text { developing learning management }\end{array}$ & 4.10 & 0.80 & 4.30 & 0.65 & high \\
\hline 14 & $\begin{array}{l}\text { Being confident with their own abilities to teach students } \\
\text { to be a good person }\end{array}$ & 4.06 & 0.86 & 4.33 & 0.71 & high \\
\hline \multirow[t]{2}{*}{15} & $\begin{array}{l}\text { Placing importance on ways to search for knowledge } \\
\text { successfully }\end{array}$ & 4.10 & 0.75 & 4.40 & 0.67 & high \\
\hline & Average summation & 4.08 & 0.79 & 4.36 & 0.65 & high \\
\hline
\end{tabular}

The objective of Clause 2 was to propose the innovation of managing classroom-based action learning in social studies to develop the professional competence of social studies teachers in the education sandbox. It was found that the researcher designed and used the 4-step learning cycle (AAAR model) for (Mangkhang, Yimsawat, Nettip, \& Kaewpanya, 2021) in developing social studies educational students' competence in learning management to support education sandbox schools and to be able to develop the project according to the school context for social responsibilities and has brought the model to develop according to the following picture. 


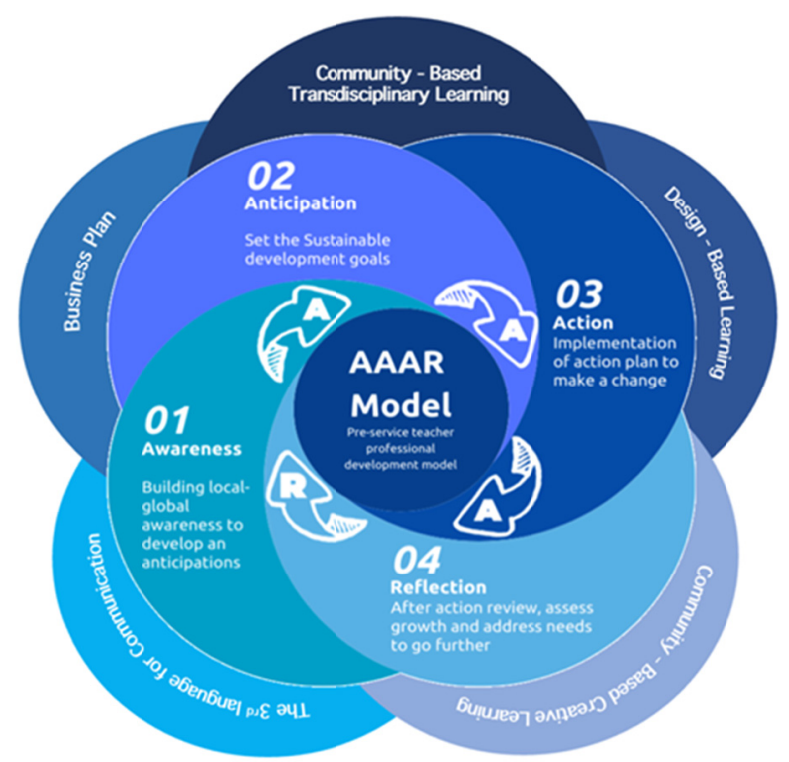

Figure 1. The 4-step learning cycle (AAAR model) for developing educational students' competence to support education sandbox schools

Source: Adapted from Mangkhang, Yimsawat, Nettip, \& Kaewpanya, 2021.

Step 1 Awareness-The step in this learning deals with building awareness to learners in various dimensions, depending on the purposes of learning or competency required to develop. Building awareness can mean awareness of one's own identity, the existence of local arts and cultures, local valuable assets which are tangible and intangible, self-worth, environmental values, respecting yourself and others; awareness of cultural and social diversities; awareness of tolerance towards social and community differences. This can also include awareness of problems or challenges such as degraded environment, poverty, climatic changes of the world, Regarding the mechanism of building awareness, teachers can use strategies and various techniques of teaching, including searching and investigating in various forms within themselves and externally to make a survey and use empirical evidence to bring about awareness building.

Step 2 Anticipation - In the anticipation step, learners use their abilities to anticipate the consequence of action in the short run and in the long run, to understand the intention of their own and of other people, including extending viewpoints of their own and other people. The learners must be aware and know that present action will bring about results in the future or on the other hand, results of things to come in the future results from present action. Therefore, in this step, the learners do not only have to ask questions about things to happen but also have to consider and anticipate the following consequences and results to occur resulting from doing one thing or not doing it by ignoring it. In participation, learners must use their abilities to understand problems, manage conflicts, cope with the stress of social phenomena or cultures, including environmental phenomena. This step has much connection with the awareness step. Therefore, designing learning activities in this step must connect with the awareness step. The important component of this step is the fact that learners must build scenarios or simulated situations in their thoughts sin order to build scenarios or vision (flash-forwards). Vision simulation of learners will help build characteristics of the thinking process which is useful for themselves in the future. Using the thinking process to build vision or thinking about simulated situations which can happen in the future is very useful because this will help learners during childhood and adulthood develop the forebrain used for the high-level thinking process.

Step 3 Action - in this step, learners perform actions to bring about better things in the life, social, economic, and environmental dimensions. This can be either physical action or conceptual action. Action will be an investigation to lead to findings. It is a matter of creating inventions, innovation, showing responsibilities in some situations, including building new values. Therefore, activities in this step are not conducted variously. They can be conducted alone or by a group but learners must be aware of the fact that any action or operation can result in positive effects or negative effects. Therefore, in this step, learners must be aware of the fact they must be responsible for the consequence of their actions. For this reason, any action or operation requires reflection of occurring results of actions passing to the next step which is the reflection or reflective thinking. 
Step 4 Reflection-This step is giving meaning to the experiences which learners have received through thinking for insight by connecting among experiences leading to building concepts. This process will help develop the thinking skills of learners, including helping learners perceive their powers in any operation and action in the future. Reflection is the process with systems, clarity, and principles originating from scientific investigation together with attitudes or values with believing in yourself and other people in terms of being able to bring about intellectual development. Reflection combines self-leading skills and creative thinking skills. Moreover, reflection can also connect issues regarding ethics, values, and motivation. Learning in this form is a cycle because the reflection step will lead to the process of building more awareness which learners have towards themselves, other people, and the surrounding society. Competence development leading to changes has been developed profoundly through the reflection process.

The following competencies of the student teachers are found as necessary and important competencies for supporting the schools in the Chiang Mai Education Sandbox Area through the learning cycle of the (AAAR model).

1) Community-based Transdisciplinary Learning is the integration of the discipline and all possible inter-disciplines with the purpose to understand the complicated world. Instead of focusing on particular field of study, the learning and problem solutions involve with the cooperation among all related sectors in the communities including the educational institutions for responding to complicated challenges through mutual learning. The study found that the best community-based transdisciplinary learning for solving problems was on the resource distribution in combination with the development as well as on the awareness of human potential promotion through the educational system. As a result, the community-based transdisciplinary learning is an outstanding process by integrating knowledge from various fields of study to solve the problems about the global effects to create new knowledge and to synthesize ideas and perspectives homogeneously in all sciences. In the community-based transdisciplinary learning needs all teachers' participation and collaboration by sharing their ideas with other people with the aim to integrate the learning experience. This process will lead the students to gain meaningful and sustainable understanding, they will eventually learn across the disciplines more than ever, and they will grow with in-depth knowledge.

2) Design-based Learning is managed for promoting the students to solve community problems in 5 steps. Step 1 is to empathize with the area contexts for studying and understanding the community conditions and geography. Step 2 is to define needs through the understanding of the problems by thinking as analyzers with the holistic systems. Step 3 is to ideate problem solutions through brainstorming for new ideas by thinking as an innovation creator based on the existing resources in the communities. Step 4 is to create an innovative prototype by researching with trial and error repetitively until obtaining the application process or knowledge from their wisdom. And Step 5 is to test the solution by using the created innovation with flexibility and expectation for practical success.

Design-based learning is the learning model which combines the design concept and process. The principle of design-based learning is on developing the students' higher-order thinking skills for solving problems, adapting themselves, and learning for the survival of people in the communities. This type of learning is regarded as the strategy for problem-solving in complicated practice with relation to the community contexts.

3) Community-based Creative Learning consists of the principles which are important and necessary for the students. Apart from creating innovation for the community, the students are trained to think up ideas for new problem-solving strategies for the communities. Community-based creative learning includes 5 steps: Step 1 to stimulate the students' interest to think up ideas and set questions; Step 2 to set questions and to divide into groups of interests; Step 3 to do research and think up creative ideas under the coaches' supervision; Step 4 to present innovation and share opinions among the classmate in the other groups, and Step 5 to evaluate the implementation.

Such process facilitates the students to develop 4 main necessary skills for the futures: 1) analytical thinking skill, 2) knowledge-seeking skill, 3) communication skill, and 4) reporting skill.

4) Business Plan is for enhancing the students' competencies after passing the competency-based curriculum (CBC) to support the students to apply their gained skills in self-employment and entrepreneurship according to their career goals.

5) The 3rd Language for Communication is one of the teacher competencies, especially in dialects/ethnic dialects for the teachers to communicate with the students properly and accurately in knowledge transfer.

If the student teachers possess these competencies, they can promote the educational management in Chiang Mai 
Province in response to the real needs of the local people, leading to the real model of the educational reform. These competencies are consistent with the competencies of "La-orn Jiangmai" (youths in Chiang Mai) which are reflected and prescribed by 104 schools in the Chiang Mai Education Sandbox Area (Chiang Mai Provincial Administration Organization, 2021). These competencies are as follows.

1) Critical thinking and learner person

2) Self-reliance and self-management

3) Communication

4) Entrepreneur and collaboration

5) Technology skills

6) Active citizens

The objective of Clause 3 was to assess the satisfaction level of students in developing professional competence of social studies teachers in education sandbox. Research results revealed the satisfaction level of using the form of developing educational students' competence to support education sandbox schools in Chiang Mai province as follows:

Table 4. satisfaction level of using the form of developing educational students' competence to support education sandbox schools in Chiang Mai province.

\begin{tabular}{|c|c|c|c|c|}
\hline \multirow[t]{2}{*}{ Order } & \multirow[t]{2}{*}{ Item } & \multicolumn{2}{|c|}{ Satisfaction } & \multirow[t]{2}{*}{ Satisfaction level } \\
\hline & & $\overline{\mathrm{x}}$ & SD & \\
\hline 1 & Learning helps promote awareness of the importance of the Lanna identity & 4.31 & 0.47 & high \\
\hline 2 & Learning helps promote understanding the community context of one's own & 4.38 & 0.68 & high \\
\hline 3 & Learning helps promote communication abilities & 4.41 & 0.57 & high \\
\hline 4 & $\begin{array}{l}\text { Learning helps promote abilities of analytical thinking and connecting thinking } \\
\text { synthesis }\end{array}$ & 4.55 & 0.57 & the highest \\
\hline 5 & Learning helps promote solution abilities and life skills development & 4.48 & 0.63 & high \\
\hline 6 & Learning helps promote entrepreneurship abilities paying attention ot consumers & 4.28 & 0.65 & high \\
\hline 7 & Learning helps promote creative ideas & 4.59 & 0.57 & the highest \\
\hline 8 & Learning gives an opportunity for actual practices & 4.48 & 0.57 & high \\
\hline 9 & Learning gives an opportunity for discussion and exchanging opinions together & 4.52 & 0.57 & the highest \\
\hline 10 & Forms of activities help develop competence meeting the needs of the community & 4.45 & 0.57 & high \\
\hline 11 & The knowledge obtained can be used to create innovation for the community & 4.55 & 0.51 & the highest \\
\hline 12 & Methods of organizing activities were suitable with the content & 4.38 & 0.68 & high \\
\hline 13 & Medias/equipment used in doing activities were suitable & 4.34 & 0.55 & high \\
\hline 14 & There was a variety, suitable for the activities & 4.38 & 0.68 & high \\
\hline \multirow[t]{2}{*}{15} & Period of time used in arranging the activities was appropriate & 3.66 & 0.81 & medium \\
\hline & Average summation & 4.38 & 0.61 & high \\
\hline
\end{tabular}

\section{Discussion}

From research results according to the objective of Clause 1, it was found that professional competence development of social studies teachers in Chiang Mai education sandbox. consisted of 4 competencies as follows: 1) Competence regarding Content Knowledge; 2) Competence regarding Learning Management; 3) Competence regarding Engagement Strategies; and 4) Competence regarding Professional Development. The first competence in the aspect of content knowledge is in line with (Selvi, 2010) in terms of the fact that competence of the curriculum can be divided into 2 subcategories which are competence of curriculum development and competence in operating the curriculum. The curriculum competence consists of knowledge about curriculum philosophy and skills in developing the curriculum, curriculum design, components of curriculum development, forms of curriculum development, guidelines of designing and developing curriculum, the process of curriculum development, system selection and organization, content, teaching conditions planning and testing and preparation, research for curriculum development. The curriculum competence is related to each other to understand in the curriculum plan of learning and teaching. Curriculum competence is the ability of teachers to focus on operation according to the role of teaching with more efficiency. These competencies are related to both theoretical competence and practical competence. These competencies are determined as abilities related to learning, teaching specifying the frame of knowledge and skills which teachers will obtain. The second competence in the aspect of learning management is in line with Wannasri (2009): 1-5 stating that skills of 
learning management which is desired teachers' competence consist of 3 aspects, namely: 1) Teaching skill is the skill in planning and designing teaching. The teaching skill can analyze and solve problems. This also includes the research skill for developing learning and teaching; 2) Skill of measuring and evaluating learning can use techniques and instruments to measure and evaluate variously and evaluation results can be used to plan for developing learners; and 3) For classroom management, atmosphere and environment can be built to support learning. Moreover, problematic behaviors of learners in the classroom can be handled as well. The third competence in the aspect of engagement strategies is in line with Salite and Pipere (2006) stating that environmental competence can be determined as competence for the safety of the ecosystem by explaining that ecology and the environment is the dimension of sustainability. Developing teachers, knowledge, attitudes ecological skills, systems, and the environment such as keeping the environment clean and available for operating, managing resources of the ecosystem with awareness of the possible ecosystem, and using natural resources. The fourth competence in the aspect of professional development is in line with Selvi (2010) stating that teachers' abilities must be mentioned in several dimensions such as field competence, research competence, curriculum competence, abilities for lifetime learning, social and cultural abilities, emotional capabilities, communication abilities, technological abilities, data communication and computer abilities, internal environment abilities for developing teachers. This is also in line with Niemi and Sihvonen (2006). Research abilities are methodology competence, techniques of designing and conducting research in the field of teachers, supporting working together with colleagues and experts or other people who are interested in studying the curriculum and education. Research abilities influence teachers in terms of monitoring the development of their fields and self-development relying on this development.

From the above-mentioned matter in developing professional competence of social studies teachers in Chiang Mai education sandbox in line with Office of the Basic Education Commission (2010): 2) analyzing components of teachers under the Office of the Basic Education Commission, it was found that functional competency consists of 6 sub-competencies, namely 1) Curriculum administration and learning management, 2) Learner development, 3) Classroom management, 4) Analysis, synthesis, and research for developing learners, 5) Teacher leadership and 6) Building relationships and cooperation with the community for learning management. This is also in line with the work of Onnuam, Junsira, Mejang and Parnichparinchai (2016) categorizing teacher competence into 3 aspects consisting of 1) Knowledge of 3 competencies, namely curriculum management, analytical thinking, synthesis and educational qualities insurance, 2) Attitude of 3 competencies, namely building relationships and cooperation with the community for learning management, acceptance, and adaptation to cultural differences and different paradigm and building traits and spirit of becoming a professional teacher and 3) Skills of 7 competencies, namely learning management and classroom management, learner development, measuring and evaluating learning, research for developing learning, using languages for communication, using innovation and educational information technology and becoming a person of learning.

Regarding the research results according to the objective of Clause 2, it was found that the 4-step learning cycle (AAAR model) for developing educational students' competence to support schools in education sandbox consists of: Step 1-Building awareness. The learning step is to cultivate awareness to learners in various dimensions, depending on the purpose of learning or competence required to develop. Building awareness includes awareness of one's own identity. This is in line with the work of Horsaengchai, Tonteerawong and Dhammahaso (2019) referring to building awareness of one's values to the youth. It is the matter of building self to individuals so that they feel confident and see values in themselves; Step 2-Determining anticipation. For this anticipation step, learners use their abilities to anticipate the consequences of action in the short run and the long run. This is in line with the work of Wongyai and Patphol (2020) mentioning the ability to see visions (flash-forwards) for changes in the future correctly by using information and the high-level analytical thinking process. The fact that possible future trends can be seen cab bring about making decisions at the present accurately; Step 3-Action. In this step, learners perform actions to bring about good things in the life, social, economic, and environmental dimensions. This is in line with the work of Inglis (1994). Learning goes through performance about which each person learns together in analyzing problems through the ongoing learning and reflection process whereby working deals with actual conditions reflection occurs on one's own experiences. This also includes proposing the approach of solving problems and implementing the approved approach of solving problems; and Step 4-reflection. This step is to give meaning to the experience which learners have received through thinking for understanding profoundly by connecting between experiences to building concepts. This is in line with the work of Wong, Frances et al. (1997) stating that learning reflection occurs when individuals connect feelings to experiences and try to explain what has happened, make a comparison and find reasons together with assessing their own. Therefore, learning reflection is the fact that one experience goes to another experience. This will keep going, leading to self-development and lifetime learning. As shown in the 
work Area-Based Learning Approach to the Competency Development of Social Studies Pre-Service Teachers in the Chiangmai Education Sandbox Area, Thailand of (Mangkhang, Yimsawat, Nettip, \& Kaewpanya, 2021).

Regarding the research results according to the objective of Clause 3, it was found that satisfaction of students in professional competency development of social studies teachers in Chiang Mai education sandbox in an overall picture was at a high level. When individual items were taken into consideration, finding revealed that students had satisfaction at a high level, accounting for 10 items. There were 4 items for satisfaction at the highest level as follows: 1) Learning helps promote creative ideas; 2) Learning helps promote abilities of analytical thinking and connecting thinking synthesis 3) The knowledge obtained can be used to create innovation for the community, and 4) Learning allows discussion and exchanging opinions together respectively. In the step of professional competency development of social studies teachers in the Chiang Mai education sandbox, there has been the development of knowledge and performance skills. As a result, students can perform and create the work, making them develop their abilities in learning better. This is in line with the concept of Council for the Curriculum, Examinations, and Assessment (2007, pp. 1-5) stating that if learners have an opportunity to express themselves and participate in learning by using learning through learning activities and innovation media in order to bring about high-level analytical thinking, this will make learners able to build knowledge, resulting in efficient learning and teaching (Jitviboon, Mangkhang, \& Dibyamandala, 2021). This includes designing creative learning activities. Encourage students to be creative and self-responsible, including in the context of classrooms and online learning.

\section{Conclusion}

In the professional competency development of social studies teachers in Thailand education sandbox, true benefits of participation in action research in the classroom or the school are the fact that educators can focus on and determine directions of growth and professional development of their truth in the specific area which schools, teachers, students, parents, and the community want to determine goals for. This brings about activities of professional development which can be tailored to meet the needs of school, teachers, and students each. Therefore, it si necessary that educational students or social studies teachers in education sandbox must have competence for 4 aspects consisting of: The first aspect deals with competence of content knowledge, knowledge about principleม, concepts, theories, subject matter of social studies, knowledge, understanding in living s being an individual and living together in the society, understanding development and changes according to ages, time, according to factors, bringing about understanding oneself and other people, having patience, tolerance, accepting differences, knowing to create harmony, having good common conscience and correct attitudes related to the nation, the country, having virtues and ethics; The second aspects deals with competence of learning management, being able to design and manage social studies learning, being able to integrate learning management, production and use of modern technological medias, organizing the environment for learning development; The third aspect deals with engagement strategies, behaving according to principles of dhamma of Buddhism or other religions which they belong to, adapting to the environment, managing limited available resources and understanding profoundly regarding the philosophy of sufficiency economy, having attitudes on working together with parents or guardians of students, making the community to participate into students' learning and promoting respecting to one another, including reinforcing unity of people in the community; and lastly the fourth aspect deals with teacher professional competence. There must be research conducted to solve problems. Regarding learner development and learning evaluation, research can be conducted and innovation can be conducted for learning development. Learners can be developed to be participants who build social studies innovation so that they can apply the knowledge to conduct life qualitatively and build a wealthy and sustainable society together creatively as well as becoming a good citizen of the country and the country and the world society.

\section{Suggestion}

From research results, the researcher has following suggestions:

\subsection{Suggestions from the Research}

From the research results, it was found that professional competency development of social studies teachers in the Chiang Mai education sandbox consisted of 4 competencies as follows: 1) Competency pf content knowledge; 2) Competency of learning management; 3) Competency of engagement strategies, and 4) Competency of professional development. Therefore, teacher-producing institutes in Chiang Mai province and agencies under the Ministry of Education should use these 4 competencies s guidelines in developing teacher professional competence in the Chiang Mai education sandbox. 


\subsection{Suggestions for Next Research}

For the issue of next research, the research should be conducted in the issue regarding:

1) Professional competence of social studies teachers in Chiang Mai education sandbox should be studied and assessed.

2) Research on and development of medias and innovation of social studies teachers in Chiang Mai education sandbox should be conducted.

\section{Acknowledgments}

We would like to thank the Faculty of Education, Chiang Mai University which has supported us in terms of a research grant on professional competence development of social studies teachers in the education sandbox.

\section{References}

Chiang Mai Provincial Administration Organization. (2013). Chiang Mai Educational Reform Strategic Plan B. E. 2556. Chiang Mai: Bureau of Education Religion and Culture.

Chiang Mai Provincial Administration Organization. (2021). Schools in Chiangmai Education Sandbox Area Project. Chiang Mai: Bureau of Education Religion and Culture.

Council for the Curriculum, Examinations and Assessment. (CCEA). (2007). Active Learning and Teaching Methods. UK: A PMB publication.

Government Gazette. (2019a). Announcement of the Ministry of Education Subject Undergraduate Qualifications standards Education (four-year course) A.D. 2019 (6 March A.D. 2019). Government Gazette Rule Number 136 Pages 12 Section Number 56 D. Retrieved October 20, 2020, from http://www.ratchakitcha.soc.go.th/DATA/PDF/2562/E/056/T_0012.PDF

Government Gazette. (2019b). Educational Innovation Area Act A.D. 2019 (30 April A.D. 2019). Government Gazette Rule Number 136 Pages 102-120 Section Number 56 A. Retrieved October 28, 2020, from http://www.ratchakitcha.soc.go.th/DATA/PDF/2562/A/056/T_0102.PDF

Government Gazette. (2020). Announcement of the Teachers Council of Thailand Board Subject Criteria and Methods for Testing and Evaluating Professional Competence of Teachers A.D. 2020 (7 May A.D.2020). Government Gazette Rule Number 137 Pages 15-19 Section Number 109 D. Retrieved November 24, 2020, from http://www.ratchakitcha.soc.go.th/DATA/PDF/2563/E/109/T_0015.PDF

Heick, T. (2020). Should Sandbox Learning Be the Future of Education? Retrieved February 22, 2021, from https://www.teachthought.com/the-future-of-learning/how-sandbox-learning-became-the-future-of-educatio $\mathrm{n} /$

Horsaengchai, S., Tonteerawong, B., \& Dhammahaso, P. H. (2019). Self-Awareness Reinforcing Model for Prevention the Risky Behavior to Suicide of Adolescents by Buddhist Peaceful Means. Journal of MCU Peace Studies, 7(Supplement Issue), S154-S167.

Inglis, S. (1994). Making the most of action learning. Hampshire: Gower Publishing Limited.

Jitviboon, K., Mangkhang, C., \& Dibyamandala, J. (2021). Challenges of Educational Management that Promotes Peace in the Digital Age Social Studies Classroom According to the Concept of Buddhadasa Bhikkhu. Psychology and Education Journal, 58(4), 2815-2822.

Mangkhang, C. (2017a). Ideology: Social Studies Curriculum for All. Bangkok: Chulalongkorn University.

Mangkhang, C. (2017b). Learning Innovation to Professional Competency in Teacher Education Institute of Thailand. Veridian E-Journal, 10(3), 317-331.

Mangkhang, C., \& Kaewpanya, N. (2021). The Scenarios Perspective of Social Studies Pedagogy to Next Citizenship in the 22nd Century. Turkish Online Journal of Qualitative Inquiry, 12(8), 5172-5180.

Mangkhang, C., Kaewpanya, N., Sombun, T., \& Pangchan, W. (2021). The Mahaboworn Model of Social Studies Learning Network Innovation to Develop of Indigenous History Learning Resources in Northern Thailand. Journal of Education and Learning, 10(5), 177-186. https://doi.org/10.5539/jel.v10n5p177

Mangkhang, C., Yimsawat, C., Nettip, A., \& Kaewpanya, N. (2021). Area-Based Learning Approach to the Competency Development of Social Studies Pre-Service Teachers in the Chiangmai Education Sandbox Area, Thailand. Journal of Education and e-Learning Research, 8(3), 264-271. https://doi.org/10.20448/journal.509.2021.83.264.271 
Mertler, C. A. (2013). Classroom-Based Action Research: Revisiting the Process as Customizable and Meaningful Professional Development for Educators. Journal of Pedagogic Development, 3(3), 38-42.

Niemi, H., \& Sihvonen, R. J. (2006). Research-based teacher education. In R. J. Sihvonen \& H. Niemi (Eds.), Research-based teacher education in Finland: Reflection by Finnish teacher educators (pp. 31-50). Turku: Paionsalama Oy.

Nilkaew, B. (1998). Study Research. Chiang Mai: Department of Evaluation and Educational Research Faculty of Education Chiang Mai University.

Office of the Basic Education Commission. (2010). Teacher Competency Assessment Manual under the Office Board of Basic Education. Bangkok: Office of the Basic Education Commission, Ministry of Education.

Office of the Education Council. (2017). National Education Plan A.D. 2017-2036 (2nd ed.). Bangkok: Office of the Education Council.

Onnuam, W., Junsira, V., Mejang, S., \& Parnichparinchai, T. (2016). A Developmental Model for Enhancing Primary Teachers' Competencies under the Office of Education Service Areas. Journal of Education Naresuan University, 18(3), 292-302.

Ralf, A. L. F., van Griethuijsen, K. E. M., van Woerkom, M., Wesselink, R., \& Poell, R. F. (2020). Does Implementation of Competence-Based Education Mediate the Impact of Team Learning on Student Satisfaction? Journal of Vocational Education \& Training, 72(4), 516-535. https://doi.org/10.1080/13636820.2019.1644364

Salite, I., \& Pipere, A. (2006). Aspect of sustainable development from the perspective of teachers. Journal of Teacher Education and Training, 6, 15-32.

Selvi, K. (2010). Teachers' Competencies. Cultura International Journal of Philosophy of Culture and Axiology, 7(1), 167-175. https://doi.org/10.5840/cultura20107133

Smolikevych, N. (2019). The teacher's main competencies in modern higher education. European Humanities Studies: State and Society, 3(1), 30-42. https://doi.org/10.38014/ehs-ss.2019.3-I.03

Tangkitvanich, S. (2020). Education Sandbox Is Thai Classroom in the 21st Century? Retrieved April 4, 2021, from

https://bookscape.co/somkiat-interview?fbclid=IwAR1R7-1A3CKqQMYuP8S_8D_hiu09W9IjvZLZ8085rI u_DWlj4ZuFFhIuPQ

Wannapaisan, C. (2020). Social Studies Research: Principle and Application (2nd ed.). Bangkok: Danex Intercorporation Company Limited.

Wannasri, J. (2009). Education Quality and Teacher Competency Desirable. Journal of Education Khon Kaen University, 32(1), 1-5.

Wong, F. K. Y. et al. (1997). An Action Research Study into the Development of Nurses as Reflective Practitioners. Journal of Nursing Education, 36(10), 476-481. https://doi.org/10.3928/0148-4834-19971201-07

Wongyai, W., \& Patphol, M. (2020). $4 A$ in Learning Management. Bangkok: Graduate School of Srinakharinwirot University.

\section{Copyrights}

Copyright for this article is retained by the author, with first publication rights granted to the journal.

This is an open-access article distributed under the terms and conditions of the Creative Commons Attribution license (http://creativecommons.org/licenses/by/4.0/). 